\title{
UNIVERSITY OF MIAMI RADIOCARBON DATES VIII
}

\section{PIEPGRAS and J J STIPP}

Department of Geology, University of Miami, Coral Gables, Florida 33124

The following radiocarbon measurements are a partial list of projects and samples dated since January 1975. The technique used is described in R, v 16, pp 402-408 and R, v 18, pp 210-220. Dates are calculated using ${ }^{14} \mathrm{C}$ half-life of $5568 \mathrm{yr}$ and errors are reported as one-standard deviation.

\section{ACKNOWLEDGMENTS}

We are grateful to D Evans, Dept Biology, for the continued supplemental use of his Packard Tri-Carb 2003 liquid scintillation spectrometer. $\mathrm{K}$ Valenziano assisted in some of the chemical preparations.

\section{SAMPLE DESCRIPTIONS}

\section{ARCHAEOLOGIC SAMPLES}

\section{Garfield series}

Freshwater shell and corn samples from the Garfield site, 9-Br-99 Bartow Co, Georgia (34 $11^{\prime} 48^{\prime \prime}$ N, 84 $58^{\circ} 04^{\prime \prime}$ W). Coll 1970 by J Chapman and 1972 by $\mathrm{J} T$ Milanich: subm 1975 by $\mathrm{J} \mathrm{T}$ Milanich, Univ Florida and T Clark, Univ Miami. Comment (JTM): the site is a single component village occupied by the Kellog culture, known to have existed from ca $500 \mathrm{BC}$ to $\mathrm{AD} 1$.

UM-445. Garfield Sq 23, Level C

Freshwater shell from midden.

UM-446. Garfield Sq 23, Level D

Freshwater shell from midden.

UM-447. Garfield Sq 500N, 565E, Feature 5

Freshwater shell from large bell-shaped storage pit.

\section{UM-448. Garfield corn}

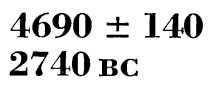

$4950 \pm 80$ $3000 \mathrm{BC}$

$5270 \div 80$

Corn from same provenience as UM-447. Corn kernels from here were previously dated at Univ Georgia at AD 700 and AD 1000.

UM-449. Garfield charred nuts

$2070 \pm 240$

Charred nuts and wood from same provenience as UM-447, -448.

\section{Red Willow Creek series}

Charcoal and freshwater shell samples from 2 levels of occupation on North bank of Red Willow Creek. Samples come from a Woodland 
period house in Red Willow Co, Nebraska ( $\left.40^{\circ} 20^{\prime} 41^{\prime \prime} \mathrm{N}, 100^{\circ} 38^{\prime} 42^{\prime \prime} \mathrm{W}\right)$ and from the Upper Republican site in Frontier Co, Nebraska $\left(40^{\circ} 22^{\prime}\right.$ $\left.50^{\prime \prime} \mathrm{N}, 100^{\circ} 43^{\prime} 52^{\prime \prime} \mathrm{W}\right)$. Coll 1962 and subm 1975 R T Grange Jr, Univ South Florida, Tampa.

\section{UM-466. Red Willow 25RW28}

$1370 \pm 100$

Charcoal from refuse pit, 76 to $91 \mathrm{~cm}$ above house floor from Woodland period.

\section{UM-469. Red Willow 25RW28}

$4950 \pm 120$

Freshwater mussel shell from refuse pit 46 to $61 \mathrm{~cm}$ above house floor.

\section{UM-470. Red Willow 25RW 28}

$1940 \pm 80$

Charcoal from refuse pit, 61 to $76 \mathrm{~cm}$ above house floor.

\section{UM-549. Red Willow 25RW28}

Duplicate run of UM-470.

General Comment (RTG): dates should give a better understanding of Woodland period culture in Plains archaeology and show possible relationships to the Massacre Canyon site and/or Kieth focus sites in the region. Charcoal from this site was previously dated $1430 \pm 45$ (SE-68) R, v 7, p 246.

\section{UM-467. Upper Republican $25 F t 80$}

$1380 \pm 180$

Charcoal from several locations in the same general occupation zone, 0 to $46 \mathrm{~cm}$ below surface.

\section{UM-468. Upper Republican 25Ft80}

Freshwater mussel shell from several locations in same occupation zone, 0 to $46 \mathrm{~cm}$ below surface.

General Comment (RTG): the Upper Republican site is on upper level of terrace in Red Willow Creek Valley. Dated to provide a better basis for comparative studies of cultures in the region. Charcoal from this site was previously dated $440 \pm 40$ (SI-72) R, v 7, pp 247.

\section{St Simons Island series}

Seven shell samples from middens of various locations on St Simons I. Glynn Co, Georgia. Coll 1974 and subm 1975 by J T Milanich, Univ Florida and A Machover, Univ Miami.

General Comment (JTM): dates correspond to Deptford and Wilmington cultures and are to check, and, if necessary, revise ceramic and cultural sequence for central coast of Georgia. 
UM-667. St Simons I. Test B-C

$$
990 \pm 80
$$

AD 960

Busycon from shell midden $\left(31^{\circ} 17^{\prime} 8^{\prime \prime} \mathrm{N}, 81^{\circ} 19^{\prime} 42^{\prime \prime} \mathrm{W}\right) 35 \mathrm{~cm}$ below surface.

\section{UM-668. St Simons I. Test D}

$1130 \pm 70$

Busycon from shell midden $\left(31^{\circ} 16^{\prime} 30^{\prime \prime} \mathrm{N}, 81^{\circ} 19^{\prime} 47^{\prime \prime}\right.$ W) $18 \mathrm{~cm}$ below surface.

\section{UM-669. St Simons I. Test F}

$1240 \pm 90$

Busycon from shell midden $\left(31^{\circ} 16^{\prime} 4^{\prime \prime} \mathrm{N}, 81^{\circ} 20^{\prime} 22^{\prime \prime} \mathrm{W}\right) 10 \mathrm{~cm}$ below surface.

\section{UM-670. St Simons I. Test G}

Oyster shell from midden $\left(31^{\circ} 17^{\prime \prime} 4^{\prime \prime} \mathrm{N}, 81^{\circ} 19^{\prime} 42^{\prime \prime}\right.$ W) ca $30 \mathrm{~cm}$ from surface.

\section{UM-701. St Simons I. Test G}

Duplicate of UM-670.

\section{UM-671. St Simons I. Test A}

$$
1240 \pm 70
$$

Oyster shell from shell heap $\left(31^{\circ} 17^{\prime} 8^{\prime \prime} \mathrm{N}, 81^{\circ} 19^{\prime} 40^{\prime \prime} \mathrm{W}\right)$. Level III, 34 to $49 \mathrm{~cm}$ below surface.

UM-672. St Simons I. Test A

$$
1190 \pm 70
$$

Oyster shell from Level IV, 49 to $64 \mathrm{~cm}$, of same shell heap as UM-671.

\section{UM-673. St Simons I. Test E}

$1015 \pm 70$

Oyster shell from midden $\left(31^{\circ} 16^{\prime} 20^{\prime \prime} \mathrm{N}, 81^{\circ} 19^{\prime} 50^{\prime \prime} \mathrm{W}\right) 15$ to $30 \mathrm{~cm}$ below surface.

\section{St John's II series}

Duplicate runs on Donax variabilis shell coll from a midden $8 \mathrm{~km}$ $S$ of Jacksonville Beach, Florida (30 $\left.16^{\prime} 47^{\prime \prime} \mathrm{N}, 81^{\circ} 23^{\prime} 09^{\prime \prime} \mathrm{W}\right)$. Coll and subm 1975 by J Miller, Tallahassee, Florida.

General Comment (JM): helps date occupation, as ceramic markers are vague.

\section{UM-702. St John's II \\ UM-703. St. John's II}

$1000 \pm 70$ AD 950

$1175 \pm 70$ AD 775 
II. GEOLOGIC SAMPLES

\section{Everglades Marsh series}

\section{A. United States}

Periphyton samples coll alive as cylindrical encrustations on Eleocharis stems (a sedge), from various locations in the Everglades marsh, Florida. Coll and subm 1975 by $\mathrm{P}$ Gleason and P Stone, Central and S Florida Flood Control Dist.

General Comment (PG): dated to determine hard water effect, and to develop a correction factor for dates on calcitic mud derived from Periphyton from similar environments.

UM-656. Everglades Marsh BC6

$134.9 \pm 0.9 \%$ modern

Carbonate fraction of Periphyton $\left(25^{\circ} 50^{\prime} \mathrm{N}, 80^{\circ} 50^{\prime} \mathrm{W}\right) 2.4 \mathrm{~m}$ above MSL. Comment (PG): hard water in contact with surface limestones and marls.

UM-657. Everglades Marsh BC7

Same as UM-656.

$135.2 \pm 1.1 \%$ modern

UM-658. Everglades Marsh 2-17CP $\quad 129.2 \pm 1.0 \%$ modern

Carbonate fraction of Periphyton (26 $16^{\circ} 56^{\prime \prime} \mathrm{N}, 80^{\circ} 25^{\prime} 10^{\prime \prime}$ W) $3.4 \mathrm{~m}$ above MSL. Comment (PG): hard water due primarily to agricultural runoff and hard ground water from canals.

UM-663. Everglades Marsh 2-17AP $\quad 127.8 \pm 1.0 \%$ modern Same as UM-658.

UM-659. Everglades Marsh 3-28AP $\quad 137.3 \pm 1.1 \%$ modern

Carbonate fraction of Periphyton (25 $48^{\prime} 55^{\prime \prime} \mathrm{N}, 80^{\circ} 43^{\prime} 15^{\prime \prime} \mathrm{W}$ ) $2.3 \mathrm{~m}$ above MSL.

UM-660. Everglades Marsh BC2,3,4,8 $132.9 \pm 0.9 \%$ modern

Carbonate fraction of Periphyton (25 $\left.50^{\prime} \mathrm{N}, 80^{\circ} 50^{\prime} \mathrm{W}\right) 2.4 \mathrm{~m}$ above MSL. Similar to UM-656 and UM-657.

UM-661. Everglades Marsh BC2,3,4,8 $130.4 \pm 1.2 \%$ modern Organic fraction of UM-660.

UM-662. Everglades Marsh BC2,3,4,8 $126.1 \pm 1.1 \%$ modern Duplicate run of UM-661.

\section{Everglades Tree Island series}

Peat samples from 3 piston cores in Everglades tree-islands, small Persea type, in Conservation Area I, the Everglades, Florida. Continuation of a study on tree-island formation (R, v 18). Coll and subm 1975 by $\mathrm{P}$ Gleason and $\mathrm{P}$ Stone and D Piepgras.

General Comment (DP): results of core 20 suggest tree-islands may form in situ, contrary to hypothesis that they break loose during flooding and settle over a younger area. 
UM-681. Core $20(3): 146$ to $156 \mathrm{~cm}$

$\left(26^{\circ} 26^{\prime} 55^{\prime \prime} \mathrm{N}, 80^{\circ} 17^{\prime} 10^{\prime \prime} \mathrm{W}\right) 5.0 \mathrm{~m}$ above MSL.

AD 1020

$930 \pm 90$

UM-687. Core $20(3): 156$ to $166 \mathrm{~cm}$

UM-682. Core 20(3) : 166 to $175 \mathrm{~cm}$

UM-683. Core 20(3): 179 to $188 \mathrm{~cm}$

UM-684. Core 20(4): 198 to $206 \mathrm{~cm}$

UM-685. Core 20(4): 217 to $226 \mathrm{~cm}$

UM-825. Core $20(4): 217$ to $226 \mathrm{~cm}$

Duplicate run of UM-685.

UM-686. Core 20(4): 307 to $315 \mathrm{~cm}$

Comment (DP): basal peat to determine onset of peat deposition.

UM-557. Core $20: 91 \mathrm{~cm}$

AD 1170

$780 \pm 70$

Comment (PG): wood dates appearance of trees on islands.

UM-651. Core 17(3): 300 to $305 \mathrm{~cm}$

$4590 \pm 100$

2640 BC

Basal peat to determine onset of peat deposition $\left(26^{\circ} 26^{\prime} 55^{\prime \prime} \mathrm{N}\right.$, $\left.80^{\circ} 17^{\prime} 10^{\prime \prime} \mathrm{W}\right)$. Collected at $5.0 \mathrm{~m}$ above MSL.

UM-665. Core 15(3): $170 \mathrm{~cm}$

$$
1280 \pm 70
$$

AD 670

Basal hammock peat dates onset of hammock peat deposition $\left(26^{\circ}\right.$ $\left.31^{\prime} 10^{\prime \prime} \mathrm{N}, 80^{\circ} 19^{\prime} 40^{\prime \prime} \mathrm{W}\right)$. Collected at $5.3 \mathrm{~m}$ above MSL.

\section{Everglades marl series}

Peat and marl samples from 2 cores in the Everglades, Florida $\left(25^{\circ} 48^{\prime} 55^{\prime \prime} \mathrm{N}, 80^{\circ} 43^{\prime} 15^{\prime \prime} \mathrm{W}\right)$. Coll and subm 1975 by P Gleason and P Stone, CSFFCD and M Kirschbaum, Univ Miami.

General Comment (PG): marl deposition correlates to a dry period in the history of the Everglades. Peat samples bracket marls to serve as a crosscheck to marl dates. Collected at $2.3 \mathrm{~m}$ above MSL.

UM-695. Core 26-2: 47 to $53 \mathrm{~cm}$

$3180 \pm 80$

Peat sample serves as a lower bracket to marl (UM-697).
$1230 \mathrm{BC}$ 
UM-696. Core 26-7 : 27 to $33 \mathrm{~cm}$

$2040 \pm 80$

$90 \mathrm{BC}$

Peat sample serves as upper bracket to marl (UM-697).

UM-697. Core 26-4,5: 37 to $44 \mathrm{~cm}$

$2440 \pm 90$

$490 \mathrm{BC}$

Periphyton marl with mullosk and gastropod shells.

\section{UM-698. Core 27-3,4: 36 to $43 \mathrm{~cm}$}

$2430 \pm 100$

480 BC

Periphyton marl with mullosk and gastropod shells.

UM-699. Core 27-1: 45 to $52 \mathrm{~cm}$

$3210 \pm 80$

$1260 \mathrm{BC}$

Peat sample serves as lower bracket to marl (UM-698).

\section{UM-700. Core 27-6: 27 to $34 \mathrm{~cm}$}

$2080 \pm 70$

130 BC

Peat sample serves as upper bracket to marl (UM-698).

$$
4520 \pm 160
$$

UM-664. Everglades peat

2570 BC

Basal peat from Everglades marsh dates onset of peat deposition. The Everglades, Florida (25 $\left.48^{\prime} 55^{\prime \prime} \mathrm{N}, 80^{\circ} 43^{\prime} 15^{\prime \prime} \mathrm{W}\right), 100$ to $105 \mathrm{~cm}$. Coll and subm 1975 by P Gleason and P Stone.

UM-556. The Everglades

Shells (Chione cancellata) from a peat core, 196 to $210 \mathrm{~cm}$, in Conservation Area $2 \mathrm{~A}$, The Everglades, Florida $\left(26^{\circ} 20^{\prime} \mathrm{N}, 80^{\circ} 24^{\prime} \mathrm{W}\right)$. Dates last marine influence in area. Coll 1974 by $\mathrm{P}$ Gleason and P Stone; subm 1975 by P Gleason.

UM-666. Lake Okeechobee Core 11(3)

$2500 \pm 80$

550 вс

Mucky peat from a core at depth $175 \mathrm{~cm}$ from Kreamer I., Lake Okeechobee, Florida $\left(26^{\circ} 46^{\prime} 00^{\prime \prime} \mathrm{N}, 80^{\circ} 43^{\prime} 30^{\prime \prime} \mathrm{W}\right)$. Dates end of peat deposition or erosional surface. Coll and subm 1975 by $\mathrm{P}$ Gleason and $\mathrm{P}$ Stone. Comment (PG): Sample collected at $4.9 \mathrm{~m}$ above MSL.

UM-635. Corkscrew Swamp CS-1 : 173 to $183 \mathrm{~cm}$

$$
4720 \pm 90
$$

2770 BC

Basal peat sample from Corkscrew Swamp Sanctuary, W of Immokalee, Florida. Dates onset of peat deposition in swamp. Coll 1975 by $\mathrm{P}$ Gleason and P Stone; subm 1975 by M Deuver, Natl Audobon Soc.

UM-653. Adams Beach salt marsh

$$
970 \pm 80
$$

AD 980

Sandy peat from a core in a salt marsh at Adams Beach, Taylor Co, Florida $\left(29^{\circ} 52^{\prime} 30^{\prime \prime} \mathrm{N}, 83^{\circ} 38^{\prime} 18^{\prime \prime} \mathrm{W}\right)$. Date may correlate to sea level rise. Coll and subm 1975 by C Wayne and R S Murali, Florida State Univ, Tallahassee, Florida. 
Baker's Haulover and Cape Florida series

Marine carbonate sediments coll by hand scooping of surface sediments at Baker's Haulover Beach (25 $54^{\prime} \mathrm{N}, 80^{\circ} 07^{\prime} \mathrm{W}$ ) and Cape Florida $\left(25^{\circ} 40^{\prime} \mathrm{N}, 80^{\circ} 10^{\prime} \mathrm{W}\right)$. Coll and subm 1975 by R Goldstein, Univ Miami. General Comment (RG): dated to compare sediment transports and to correlate sediment size with age.

UM-674. Cape Florida, A: 250 to $5000 \mu$

UM-675. Baker's Haulover, B : 250 to $500 \mu$

UM-676. Cape Florida, A: 125 to $250 \mu$

UM-677. Baker's Haulover, B : 2000 to 4000

UM-678. Baker's Haulover, B: 125 to $250 \mu$

UM-679. Cape Florida, A: 2000 to $4000 \mu$

UM-680. Baker's Haulover, B : 2000 to $4000 \mu / B$

$$
\begin{aligned}
& 3660 \pm 100 \\
& 1710 \text { BC } \\
& 5090 \pm 110 \\
& 3140 \text { BC } \\
& 2700 \pm 80 \\
& 750 \text { BC } \\
& 5550 \pm 100 \\
& 3600 \text { BC } \\
& 5180 \pm 160 \\
& 3230 \text { BC } \\
& 6320 \pm 130 \\
& 4370 \text { BC }
\end{aligned}
$$

$12,515 \pm 360$

10,565 вC

\section{Central Delaware shelf series}

Shells from 2 cores off Delaware coast. Dates sedimentation rate during Holocene transgression. Coll 1973 by R E Sheridan; subm 1974 by M S Lipp and W L Stubblefield, NOAA.

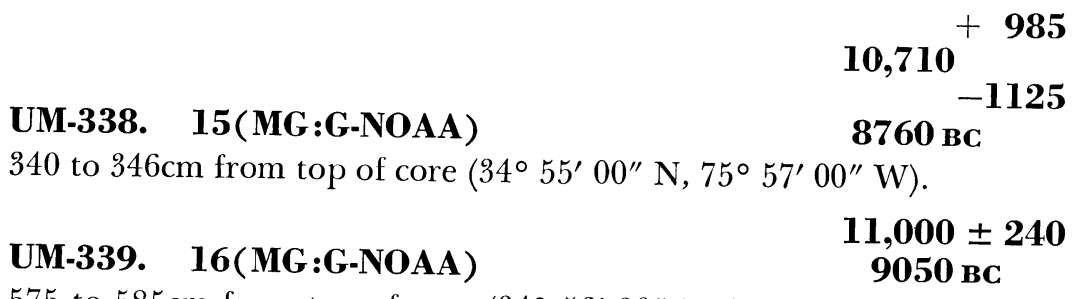

575 to $585 \mathrm{~cm}$ from top of core $\left(34^{\circ} 56^{\prime} 30^{\prime \prime} \mathrm{N}, 75^{\circ} 53^{\prime} 42^{\prime \prime}\right.$ W). Comment (WLS): previously dated by Teledyne Isotopes, Inc (unpub) at 12,400 вр.

\section{Desoto Canyon series}

Core of calcareous mud from continental slope, Desoto Canyon, Gulf of Mexico $\left(29^{\circ} 00^{\prime} \mathrm{N}, 87^{\circ} 36^{\prime} \mathrm{W}\right)$. Continuation of a study on paleoclimatology of Quaternary sediments from NE Gulf of Mexico (R, v 17, p 241-242; Emiliani et al, 1975). Coll 1974 by S Gartner; subm 1975 by C Emiliani and L Ling, Univ Miami.

UM-688. GS7102-7, 3 to $8 \mathrm{~cm}$ 
UM-689. GS7102-7, 72 to $77 \mathrm{~cm}$

$8965 \pm 180$

UM-690. GS7102-7, 161 to $163 \mathrm{~cm}$

UM-690. GS7102-7, 161 to $163 \mathrm{~cm}$

7015 BC

UM-690. GS71027, 161 to $163 \mathrm{~cm}$

$16,660 \pm 500$

$14,710 \mathrm{BC}$

UM-691. GS7102-7, 211 to $219 \mathrm{~cm}$

${ }_{19,020}^{+470}$

$17,070 \mathrm{BC}$

$21,850+590$

UM-692. GS7102-7, 221 to $228 \mathrm{~cm}$

19,900 вС

UM-693. GS7102-7, 341 to $349 \mathrm{~cm}$

$15,560 \pm 420$

13,610 вс
UM.693. GS71027, 341 to $349 \mathrm{~cm}$
UM-694. GS7102-7, 351 to $358 \mathrm{~cm}$$$
\text { B. Italy }
$$

\section{UM-548. Tyrrenian Sea, T71-3 16}
22,570
$+1320$
$-1590$
20,620 BC

$$
\begin{aligned}
& 20,290 \pm 710 \\
& 18,340 \text { BC }
\end{aligned}
$$

Siderite $\left(\mathrm{FeCO}_{3}\right)$ from top of core from the Tyrrenian abyssal plain $\left(39^{\circ} 45^{\prime} \mathrm{N}, 14^{\circ} 30^{\prime} \mathrm{E}\right)$. Dated to determine origin of siderite. Coll 1974 by R Sartori, CNR Bologna, Italy; subm 1975 by E Bonatti, RSMAS, Miami, Florida.

$$
\text { C. St Croix }
$$

\section{UM-420. Westend Saltpond}

$$
2155 \pm 170
$$

205 BC

Peat from core taken at Westend Saltpond, St Croix, Virgin Islands $\left(17^{\circ} 41^{\prime} 13^{\prime \prime} \mathrm{N}, 64^{\circ} 53^{\prime} 21^{\prime \prime} \mathrm{W}\right)$. Date for Holocene sea level records. Coll 1974 by L C Gerhard, West Indies Lab, St Croix; subm 1975 by L C Gerhard and E Swietelsky, Univ Miami.

\section{Bahamas}

\section{Tongue of the Ocean series}

Coral, sclerosponge, and sediment samples blasted from reef wall at various locations along the Tongue of the Ocean, Bahamas. Coll and subm 1976 by W Schlager, RSMAS, Miami.

UM-708. 76-5-4

$125 \pm 80$ AD 1825

Sclerosponge in $82.3 \mathrm{~m}$ water $\left(24^{\circ} 02^{\prime} 00^{\prime \prime} \mathrm{N}, 77^{\circ} 10^{\prime} 45^{\prime \prime} \mathrm{W}\right)$. Date for stratigraphy of reef wall.

UM-709. 76-5-7

$4460 \pm 90$

Coral (Porites) from same location as UM-708. 
UM-710. 76-6-1

$8310 \pm 80$

Coral $\mathbf{6 3 6 0} \mathbf{~ B C}$

Coral (Montastrea annularis) from same location as UM-708, at depth $137 \mathrm{~m}$.

\section{UM-713. 76-14-1}

$10,000 \pm 85$

8050 BC

Coral (Montastrea annularis) from depth $95.1 \mathrm{~m}\left(23^{\circ} 29^{\prime} 42^{\prime \prime} \mathrm{N}, 76^{\circ}\right.$ $34^{\prime} 06^{\prime \prime} \mathrm{W}$ ). Comment (WS): UM-709, -710 , and -713 are shallow water corals that probably grew during a lower stand of sea level.

\section{UM-711. 76-9-2A}

$770 \pm 60$

Oolites from depth $82.9 \mathrm{~m}\left(24^{\circ} 02^{\prime} 24^{\prime \prime} \mathrm{N}, 77^{\circ} 11^{\prime} 12^{\prime \prime} \mathrm{W}\right)$.

\section{UM-712. 76-9-2B}

$3490 \pm 85$

Lithified skeletal and ooid sand from same location as Comment (WS): UM-711 and -712 (tate selinent as U-711. wall.

\section{Fresh Creek series}

Carbonates from Andros I. adjacent to runway at Fresh Creek (24 $\left.41^{\prime} 53^{\prime \prime} \mathrm{N}, 77^{\circ} 48^{\prime} 37^{\prime \prime} \mathrm{W}\right)$. Dated to determine if marine sediments are a source of $\mathrm{CaCO}_{3}$ in freshwater sediments deposited by Fresh Creek. Coll 1974 and subm 1975 by P Gleason and P Stone.

\section{UM-631. Fresh Creek 1}

Oolitic limestone bedrock coll at surface.

\section{UM-632. Fresh Creek 2}

Brackish marine carbonate, surface sediment.

\section{UM-633. Fresh Creek 3}

Silt size freshwater calcitic mud coll in a living algal mat.

$$
\begin{aligned}
& 14,560 \pm 230 \\
& 12,610 \mathrm{BC}
\end{aligned}
$$

$$
\begin{aligned}
& 2900 \pm 120 \\
& 950 \mathrm{BC}
\end{aligned}
$$

\section{REFERENCES}

Eldridge, K L, Stipp, J J and Cohen, S J, 1975, University of Miami radiocarbon dates III: Radiocarbon, v 17, p 239-246.

Emiliani, C, Gartner, S, Lidz, B, Eldridge, K, Elvey, D K, Huang, T C, Stipp, J J, and Swanson, M, 1975, Paleoclimatological analysis of late Quaternary cores from the Northeastern Gulf of Mexico: Science, v 189, p 1083-1088.

Long, Austin, 1965, Smithsonian Institution radiocarbon measurements II: Radiocarbon, v 7, p 245-256. Stipp, J J, Eldridge, K L, and Cadwell, R, 1976, University of Miami radiocarbon
dates VI: Radiocarbon, v 18, p 210-220.

Stipp, J J, Elridge, K L, Cohen, S J, and Webber, K, 1974, University of Miami radiocarbon dates I: Radiocarbon, v 16, p 402-408.

Stipp, J J, Eldridge, K L, and Valenziano, K, 1976, University of Miami radiocarbon dates VII: Radiocarbon, v 18, p 371-375. 